\title{
Using Dynamic Value Stream Mapping And Lean Accounting Box Scores To Support Lean Implementation
}

\author{
Stephen L. Woehrle, Ph.D., Minnesota State University, Mankato, USA
}

Louay Abou-Shady, MS., Minnesota State University, Mankato, USA

\begin{abstract}
Lean has proven to be an effective management philosophy for improving businesses in a competitive market by eliminating waste and improving operations. An impact of implementing lean projects is the rapid reduction in inventory levels, which gives management the false impression that profits are decreasing while workers on the shop floor observe improvements in operations and increased floor space. This paper explores the literature on lean manufacturing, value stream mapping (VSM), Simulation and lean accounting in order to incorporate and integrate them for the purpose of solving the dilemma between lean implementation benefits and financial and accounting reporting methods.
\end{abstract}

Keywords: lean accounting, lean manufacturing, simulation

\section{INTRODUCTION}

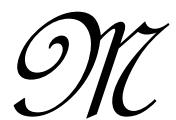

any major businesses in the United States have been trying to adopt lean manufacturing principles in order to stay competitive in a global market that is characterized by increased competition and customer expectations. Many businesses have found lean philosophy to be the potential solution over other improvement methodologies and approaches for businesses trying to focus on waste elimination and producing products that meet customer expectations in terms of quality and on-time delivery. Although the lean approach is promising, the progress of adopting it by manufacturing companies has been progressing slowly in the US and Europe, according to Lian and Landeghem (2007), because traditional manufacturers, from both operational and financial perspectives, question the effectiveness of lean transformation.

From the operational point of view, traditional manufacturers are reluctant to implement lean ideas because they cannot quantify and project the benefits that they can gain by implementing it. As Detty and Yingling (2000) state: "The decision to implement lean manufacturing, as just described, is a difficult one because of the substantial differences between traditional and lean manufacturing systems in employee management, plant layout, material and information flow systems, and production scheduling/control methods. These differences make it difficult for organizations that have historically relied on traditional manufacturing methods to predict the magnitude of the benefits to be achieved by implementing lean principles in their unique circumstances. As a result, the decision whether or not to adopt lean manufacturing techniques often must be based on a combination of faith in the lean manufacturing philosophy, the reported experiences of others who have previously adopted these principles, and general rules of thumb on anticipated benefits. For many management teams, such faith-based justification is insufficient to convince them to adopt lean concepts."

From the financial point of view, one of the wastes that lean implementation eliminates quickly when applied is excess inventory. Lower inventory levels negatively affect the bottom line of the financial statement and a misleading impression is taken that lean is not improving the business and should be stopped. As a result of misinterpreting lean operationally and financially, some managers stand against any progress taken for lean implementation and improvement initiatives. 
This study compiles and analyzes the literature, addressing the subjects of simulation, value stream mapping (VSM), and box scores. It shows how simulation with VSM along with using lean accounting box scores can bridge both the operational and financial views in one pool in order to support management in taking lean initiative decisions with higher degrees of confidence. This paper gives an overview of lean manufacturing, explains how box scores are used as a complementary tool for lean accounting to fill the gap between financial and operations managers, and shows how simulation can be used to support the decision of implementing lean manufacturing. Finally, the authors provide recommendations that can help in supporting the implementation of lean philosophy.

\section{OVERVIEW OF LEAN MANUFACTURING}

According to Womack and Jones (2003), who are internationally renowned management analysts, there are five basic principles a company or organization should follow in order to embrace the lean thinking characteristics. The major goal of those principles is to reduce cost by eliminating waste. Waste consists of all activities that do not add value from the customer's point of view. Reducing cost is also emphasized by Narasimhan, Parthasarathy, and Narayan (2007). The Womack and Jones' principles are:

1. Specifying value by determining what the customer values in a product or services.

2. Defining the value stream for a specific product or product family along a value stream and eliminating non-value-added activities (NVA) as perceived by the customer so that the product or service is delivered to the customer in the most efficient way.

3. Getting the product or service to flow by creating continuous flow for the value-added activities (VA), and replacing "batch and queue" with single-piece flow.

4. Creating a pull mechanism from the customer by making what the customer wants and when they want it by establishing takt time, and regulating inventories.

5. Striving for perfection through continuous lean journey.

There are seven types of waste (muda in Japanese) that lean focuses on reducing, if not eliminating (Narasimhan et al., 2007; MCS Media, 2006; El-Haik \& Al-Aomar, 2006). They are: overproduction, waiting time, transportation, over-processing, inventory, motion and scrap. Figure 1 shows those sources of waste graphically. As a result of waste reduction, improvements emerge in reduction of operating cost, productivity, quality and on-time delivery of products (Narasimhan et al., 2007)

Figure 1: Sources of waste in any production system

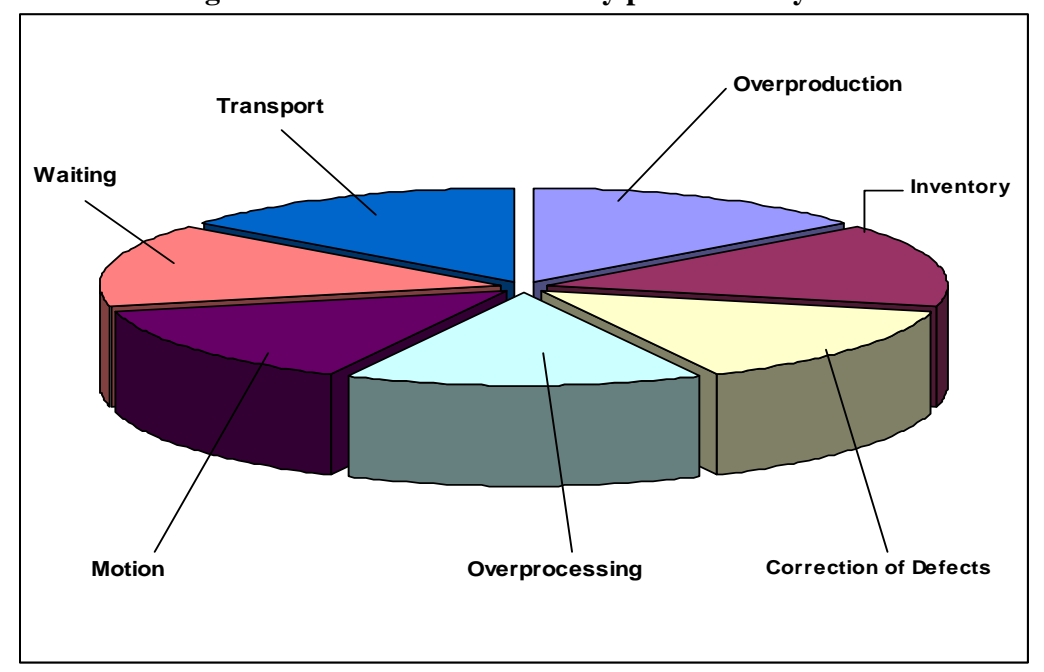


Narasimhan et al., (2007); MCS Media (2006);and El-Haik and Al-Aomar (2006) describe each source of waste as:

- Defects: making mistakes in the production process that results in generating reworked or scrapped products

- Inventory: the buildup of excessive inventory in the form of raw material, work-in-process, and finished items

- Motion: unnecessary movements of workers or machines before, after, or during processing

- $\quad$ Over-processing: unnecessary and non-value added usage or processing of equipment, tools, and materials

- $\quad$ Over-production: producing more than required quantities of products

- Transportation: unnecessary and excessive movement of materials or parts within the production line, the warehouse, or the storage area

- Waiting: parts or materials waiting in queues for being processed

There are many tools of lean manufacturing that can be used to eliminate waste. MCS Media Inc. has developed a Lean Tool Usage Matrix in its Lean Pocket Guide to help organize the application of those tools throughout lean implementation. Figure 2 shows the Lean Tool Usage Matrix.

Figure 2: Lean tool usage matrix

\begin{tabular}{|c|c|c|c|c|c|c|}
\hline \multicolumn{7}{|c|}{ Lean Tool Usage Matrix } \\
\hline LEAN TOOL & $\begin{array}{l}\text { PLAN/ } \\
\text { ENABLE }\end{array}$ & DEMAND & FLOW & LEVELING & $\begin{array}{l}\text { VISUAL } \\
\text { CONTROL }\end{array}$ & GENERAL \\
\hline $5 S$ & $x$ & & & & 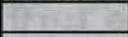 & \\
\hline $\begin{array}{l}\text { Buffer and Safety } \\
\text { Stock }\end{array}$ & & $x$ & & & & \\
\hline Cellular Layout & & & $x$ & & & \\
\hline Continuous Flow & & & $x$ & & & \\
\hline Cycle Time & & $x$ & & & & \\
\hline Heijunka (Leveling) & & & & $x$ & $x$ & \\
\hline Jidoka & & & & & $x$ & \\
\hline Just-In-Time & 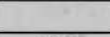 & + & $\mathrm{x}$ & & & +2 \\
\hline Kaizen & $x$ & & & & & \\
\hline Kanban & & & & & $x$ & \\
\hline Lean Metrics & $x$ & & & & & \\
\hline Lean Office & $\mathrm{x}$ & $x$ & $x$ & $x$ & $\mathrm{x}$ & \\
\hline Lean Reporting & $x$ & & & & & \\
\hline Line Balancing & & & $x$ & & & \\
\hline Mistake-Proofing & & & & & $x$ & \\
\hline Origins of Lean & & & & & +2 & $x$ \\
\hline Paced Withdrawal & & & & $\mathrm{x}$ & & 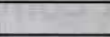 \\
\hline $\begin{array}{l}\text { Perishable Tool } \\
\text { Management }\end{array}$ & & & & & & $x$ \\
\hline Pitch & & $x$ & & + & & \\
\hline PQ Analysis & & $x$ & & & & \\
\hline Problem Solving & $x$ & & & & & $\mathrm{x}$ \\
\hline Quick Changeover & & & $x$ & & & +2 \\
\hline Runner & & & & $\mathrm{x}$ & & \\
\hline $\begin{array}{l}\text { Sequence to Lean } \\
\text { Implementation }\end{array}$ & $x$ & & & & & \\
\hline Six Sigma & $x$ & $x$ & $x$ & $x$ & $x$ & $x$ \\
\hline Standard Work & & $x$ & & & $\mathrm{x}$ & \\
\hline Storyboard & $x$ & & & & $\mathrm{x}$ & \\
\hline Takt Time & & $x$ & & & & \\
\hline $\begin{array}{l}\text { Total Productive } \\
\text { Maintenance }\end{array}$ & & & $x$ & & & \\
\hline $\begin{array}{l}\text { Value Stream } \\
\text { Management }\end{array}$ & $x$ & & & & & \\
\hline $\begin{array}{l}\text { Value Stream } \\
\text { Mapping }\end{array}$ & $x$ & & & & & \\
\hline Visual Factory & & & & & $x$ & \\
\hline Waste & & & & & & $x$ \\
\hline
\end{tabular}

Source: MCS Media, The Lean Pocket Guide XL, 2006, pg xii 
All the literature writing about the benefits of lean manufacturing agree that lean helps in eliminating waste and reducing cost. Lean offers many benefits including lead time reduction, improvement in productivity, accomplishing highest standards of quality, providing on-time product delivery, decreased work-in-process inventory, reduction of floor space due to elimination of certain non-value added ( NVA) activities, and increased resource utilization.

\section{AN APPLICATION OF VALUE STREAM MAPPING (VSM)}

Figure 3: VSM icons

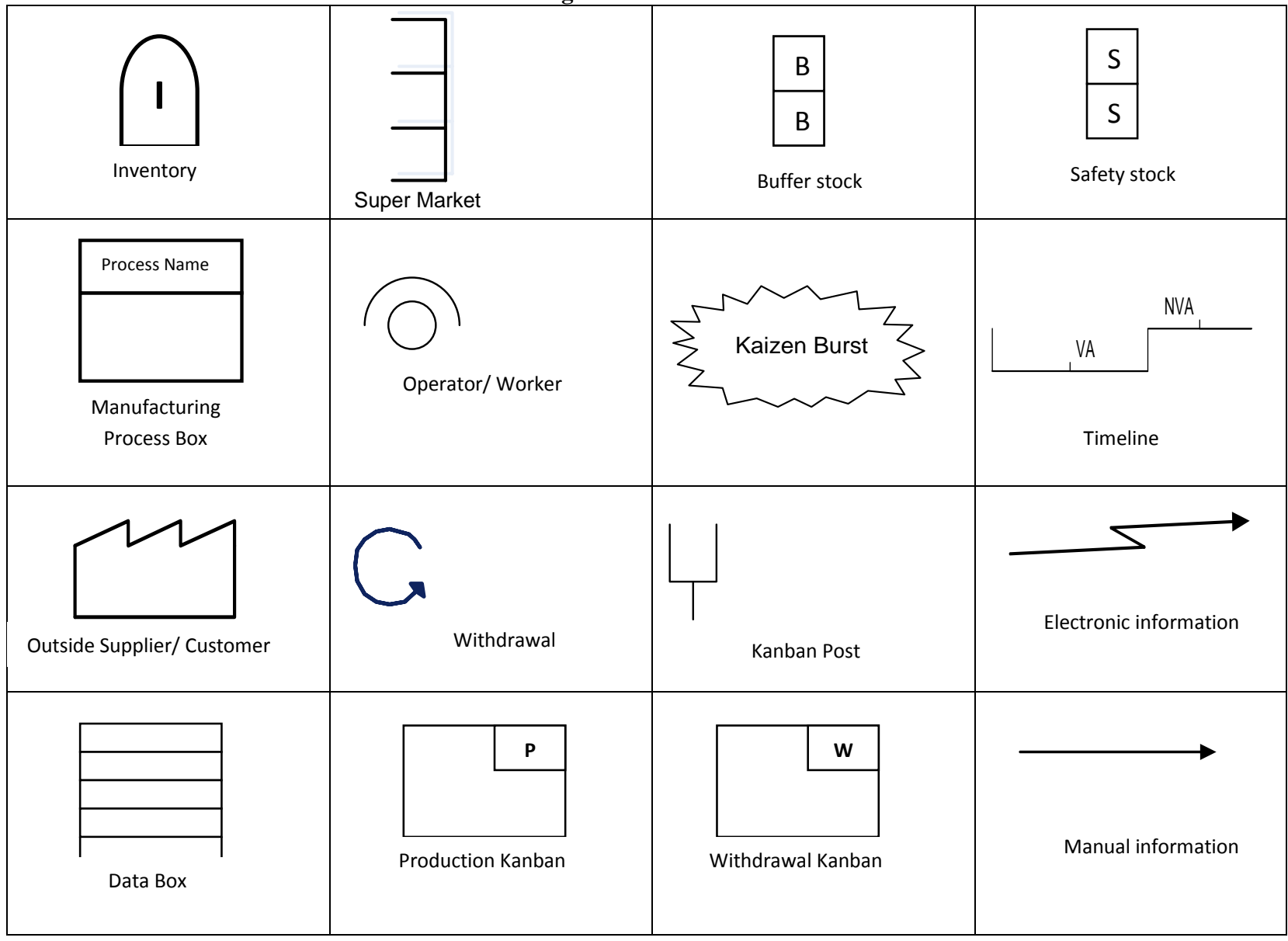

The first step in creating a VSM is to select a product or product family, according to Rother \& Shook (2003); Braglia, Carmignani, and Zammori (2006); as well as Laburu, Lasa, and Vila (2008). The second step is to construct a Current State Map, CSM, using a paper and pencil for the selected product or product family and show both the information and material flows in the value stream. Figure 2, in the VSM case study conducted by the authors, shows a CSM for a car assembly plant using the icons shown in Figure 3. The third step is to identify and analyze the seven possible sources of waste from CSM that were originally defined by Toyota and might be encountered along the value stream. Those sources of waste were shown in the pie chart of Figure 1. The fourth step is to develop a Future State Map (FSM), after removing the identified sources of waste from the CSM and answering the eight design questions identified by Rother \& Shook (2003) and shown in Figure 4. Figure 6 shows the FSM after applying step number three. Laburu et al. (2008) covers two additional steps. They are: defining a working plan for the future state and achieving that working plan. These steps are concerned with value stream maps that are linear in nature. There are two additional steps for Value Stream Maps that are complex and non-linear, 
described by Braglia et al. (2006). They are identifying machine sharing and mapping the critical path followed by a number of iterations of new critical paths.

Figure 4: Design questions for future state map

\begin{tabular}{|l|l|}
\hline \multirow{4}{*}{ Basic } & 1. What is the takt time? \\
\cline { 2 - 2 } & 2. Will finished goods be built to replenish a supermarket, or will they be built and directly shipped to clients? \\
\cline { 2 - 2 } & 3. Where can continuous flow processing be utilized? \\
\cline { 2 - 2 } & 3. Is there a need for a supermarket pull system within the value stream? \\
\cline { 2 - 2 } & 5. What single point in the production chain will be used to schedule production? \\
\hline \multirow{2}{*}{ Heijunka } & 6. How will the production be leveled at the pacemaker process? \\
\cline { 2 - 2 } & 7. What increment of work will be consistently released from the pacemaker process? \\
\hline Kaizen & 8. What process improvements will be needed? \\
\hline
\end{tabular}

\section{LEAN ACCOUNTING AND BOX SCORES}

\section{Introduction to Lean Accounting}

Lean accounting is a new accounting approach that emerged with the rise of business interest to embrace the lean thinking culture. Lean accounting aims to measure the monetary impact of implementing lean improvement projects to business processes.

Traditional cost accounting works better when applied in a production environment that supports massproduction. However, when it comes to lean transformation, the traditional cost accounting becomes hostile to lean since the lean methods "violate the rules of mass-production" (Maskell \& Baggaley, 2004). Many companies fail to see corresponding lean improvement impacts on their financial statements while workers on the shop floor can see those improvements directly, resulting in frustration caused by the gap between the operational and financial views. One of the reasons behind such a gap is that traditional accounting ignores intangible nonfinancial performance measurements, such as on-time delivery and customer satisfaction that lean accounting stresses. Figure 5 shows the operational improvements that lean accounting can bring and their status from the financial point of view.

Figure 5: Operational improvement vs. financial view

\begin{tabular}{|l|l|}
\hline Operational Improvement & Financial view \\
\hline Lead time reduction & Not recognized \\
\hline Quality improvement & Not recognized \\
\hline On-time delivery improvement & Not recognized \\
\hline Reduction in floor space & Not recognized \\
\hline Increase in inventory turns & Decrease in operating profitability \\
\hline
\end{tabular}

Looking closely at Figure 10, lead time reduction can result in a quicker revenue gain. Quality improvement and on-time delivery can increase customer satisfaction and contribute to long-term revenue increase. Moreover, quality improvement frees up resources used for rework (the "invisible" factory). Reduction in floor space can result in bringing new equipment that produce new products and expand the business, or making outsourced products in-house. Increased inventory turns have two contradicting impacts. From one side, an increase in inventory turns brings in cash quickly leading to increased cash flow that shows up in the Balance Sheet. On the other hand, increased inventory turns leads to a reduction in on-hand inventory causing a negative impact on the gross profit in the financial statement.

Carnes and Hedin (2005) explained that the increase in inventory and cost of ordering and holding it does not show up as costs until products are sold. Meade, Kumar, and Houshyar (2006) explained in detail that: "the product is stored in a warehouse facility until disposed of. These costs are not included in the current period's income statement; instead, they are recognized in a future period when they are removed from inventory, either as a result of a sale or as a result of being scrapped as obsolete or otherwise unacceptable inventory. Cost accounting is 
especially problematic for lean during the financial periods when inventory is being reduced, according to Dwyer (2005), Maskell and Kennedy (2007), Jusko (2007), and Drickhamer (2004). Kennedy and Brewer (2006) added that producing inventory does not generate revenue as long as it is not sold. They agree with Meade et al.(2006) and consider inventory as a sunk cost since the cash it consumes in storing and transporting it can be invested somewhere else (Brewer and Kennedy, 2006).

\section{Value Stream Box Score (VSBS)}

The disconnect between the shop floor and the financial statement can be bridged by utilizing and choosing performance measures that support lean continuous improvement. Cunningham and Fiume (2003) suggested that those performance measures need to support the company's strategy; be relatively few in number, mostly nonfinancial, structured to motivate the right behavior, and be simple and easy to understand. They also suggest that the performance measures need to measure the process, not people, actual results versus goals and be timely.

VSBS is one of the lean accounting tools that satisfy the criteria set by Cunningham and Fiume (2003) to choose performance measures. According to Dwyer (2005), a box score process is "a spreadsheet-based technique" that is used to identify performance against target. Maskell and Kennedy (2007) agreed with Dwyer (2005) and added that the box score format is used to summarize the weekly progress reporting of the value stream in terms of performance, decision making, and prioritizing lean improvement initiatives. By tracking the value stream records weekly, the targeted Future State (FS) is kept in full view (Maskell and Kennedy, 2007).

VSBS is a means to bridge both the financial and operational views of lean in one pool. Because VSBS is considered a box score for value stream, a pre-requisite to construct a VSBS is to create the Current State VSM (CVSM). The CVSM is considered the base of any lean improvements, highlighting the possible sources of waste and being the baseline to measure the improvement changes that result from the lean transformation. Then, the Future State VSM (FVSM) is constructed to show the expected benefits from applying lean principles. The variance is considered as the difference between CVSM measures and the expected FVSM benefits.

If the company's strategy, for example, is to achieve the FS goals in a certain time span, the box score can be broken into weekly performance measures that monitor the progress towards the target results. The performance measures can be displayed visually by being posted on display boards on the shop floor. This way, everyone can be aware of the progress of improvement efforts the company has set.

\section{SIMULATION}

\section{Definition}

According to El-Haik and Al-Aomar (2006), simulation is imitating the activity of the operation of a real system, in a computer, with a focus on process flow, logic, and dynamics. In other words, it is considered a representation of the real-world system. Furthermore, according to Harrel, Ghosh, and Bowden (2004), it is "the imitation of a dynamic system using a computer model in order to evaluate and improve system performance". Harrel and Tumay (1995) add to these definitions the fact that simulation is considered a solution evaluator rather than a solution generator as it directs towards "the best workable solution". Therefore, simulation can be considered a disciplined process of building a model similar to a real one, and performing experiments with it in order to analyze, understand, and evaluate its operational strategies through computer software and "what-if" scenarios.

\section{Simulation in Support of VSM and Lean Manufacturing}

The lean approach is apparently simple. However, adopting such an approach is progressing very slowly among manufacturing companies for several reasons. One of the reasons is that the impact of lean transformation is difficult to determine accurately and in a timely manner (Lian and Van Landerhem, 2007). Another reason is the uncertainty associated with the effectiveness of applying changes related to expensive factory layout redesigns, such as replacing large mass production machines by smaller machines in manufacturing cells (Lian and Van Landerhem, 2007). When it was first used, VSM application helped in visualizing the benefits of applying lean principles. 
However, it had several limitations that prevented it from being applied in a broader perspective. Therefore, the VSM limitations have created a need to develop complementing tools to enhance and widen its applications. Using simulation tools fulfills that need.

The fusion of simulation with VSM has countered the limitations of traditional VSM. McDonald et al (2002) and Lian and Van Landeghem (2002) showed in their case studies that discrete event simulation can provide important information for implementing FSM in complex production systems (Barglia et al.,2006). This way, the limitation of using traditional VSM for complex systems is eliminated by integrating simulation with VSM. Simulation also supports the reduction of uncertainty and the creation of shared consensus about the process since it helps visualize the process dynamic views of given future states before implementation, as addressed by Mcdonald et al., (2002). Narasimhan et al. (2007) also support that point by explaining that simulation results can increase management confidence in applying lean. Detty and Yingling (2000) add that simulation can help in raising more confidence and commitment to adopt lean principles by quantifying the expected outcomes of applying lean.

There are some benefits of integrating simulation with VSM for the purpose of implementing lean principles. Abdulmalek and Rajgopal (2006) developed a simulation model to contrast CSM and FSM of a continuous process production system in order to demonstrate to managers the potential benefits of using VSM, such as eliminating waste, maintaining better inventory control, improving product quality, and obtaining better overall financial and operational control. El-Haik and Al-Aomar(2006) suggested that the CSM helps in providing input data for building a dynamic CSM model by using DES that can capture the stochastic process behavior as it develops over time. The collected statistical outcomes of the DES then can be used to develop a dynamic CSM that better represent the actual process time line and performance measures. This dynamic CSM is the basis for developing robust and dynamic future state maps that are more reliable in evaluating various improvement scenarios and making more effective decisions. Additional benefits can be summarized in the points below:

- $\quad$ Simulation helps in exploring several alternatives to the future state that can be generated by having different responses to the eight design questions addressed in Table 3.1 (Mcdonald et al., 2002).

- $\quad$ Simulation can help management get a better comparison between the performance of the existing system and that of the suggested lean system, thus convincing management to adopt lean (Abdulmalek and Rajgopal, 2007).

- Discrete Event Simulation (DES) with VSM can help organizations quantify the expected benefits of lean manufacturing at the planning and evaluation stage (Detty and Yingling, 2000).

- The information generated from the DES can be used as a benchmark to measure the effectiveness of implementing the lean changes (Detty and Yingling, 2000).

\section{Simulation in Support of Financial Analysis and Lean Manufacturing}

In their research paper, Meade et al.(2006) used Hybrid Simulation Modeling ( by using Microsoft Excel, Manufacturing Resource Planning (MRPII), and Promodel simulation software) to quantify the negative impact of lean manufacturing implementation (in terms of duration and magnitude) on reported profits as inventories are being reduced. ProModel simulation software was used to develop and operate the model production environment according to Houshyar et al. (2006). They used simulation to mimic a lean implementation scenario in a real-world manufacturing environment. The purpose of that simulation project was to generate data to provide a series of income statements for several accounting methods over a series of simulated months in order to study the impact of reduced inventories on the income statement bottom line. They confirmed that successful lean implementation projects will definitely lower all inventories, such as raw materials, WIP, and finished goods so rapidly that those projects will be misunderstood as a failure due to the profound impact of reduced inventories on the resulting reported net profit, as described by Houshyar et al. (2006). As a result, improved lean operational performance, such as reduced delivery lead times and physical plant space, will be counteracted by the existing traditional accounting systems, as described by Houshyar et al. (2006). 


\section{CONCLUSION AND RECOMMENDATIONS}

This paper demonstrates that simulation can be considered an integral part of VSM and can be used as a visual tool to convince management to adopt lean from both operational and financial perspectives. Simulation accomplishes this is by developing replicas of real-life and suggested models in order to give a better comparison between the performance of the existing system and that of the suggested lean system. Simulation and VSM can also help provide a solution for the drawbacks encountered when using the static VSM in terms of predicting the inventory levels throughout the value stream. This feature can show management that traditional accounting methods, when implementing lean accounting will be harmful to reported business profits. This is one of the major reasons behind management's reluctance to adopt lean principles. In addition, VSBS can be used on the shop floor as a means to get both operational and financial personnel together to achieve a mutual understanding regarding the benefits of monitoring and improving lean implementations. Therefore, simulation and VSBS are effective complementary tools with VSM. Simulation can quantify both the operational and financial gains during the early planning and assessment stages of lean implementation while VSBS can help in measuring and controlling the progress of implementing lean philosophy.

The authors suggest four recommendations for further study. The first suggestion is to involve both the CFO and the controller to physically participate in kaizen events to see and feel the benefits of eliminating waste on the shop floor. The second suggestion is to promote hands on involvement by the accounting community, also subscribed to by Deluzio (2006). This involvement encourages the finance and accounting executives to make sure that those benefits are recognized in their financial statements, enabling an accounting approach that can be integrated with lean and satisfy both generally accepted accounting principles (GAAP) and the Internal Revenue Service. The authors' third suggestion is that simulation can be another alternative (for the financial and accounting executives) to being physically on the shop floor. Fourth, simulation can be considered an effective tool to be used for demonstration, for financial and accounting executives who are distant from the shop floor due to geographic location constraints. In conclusion, the authors suggest developing simulation software that can be broadcast online for organizations having international locations.

\section{AUTHOR INFORMATION}

Stephen Woehrle teaches both undergraduate and graduate management accounting at Minnesota State University, Mankato. As his graduate advisor, Dr. Woehrle collaborated with Louay Abou-Shady on this paper in partial fulfillment of Mr. Abou-Shady's Master of Science Degree in Manufacturing Engineering Technology at Minnesota State University, Mankato.

\section{REFERENCES}

1. Abdulmalek, F., \& Rajgopal, J. (2007, May). Analyzing the benefits of lean manufacturing and value stream mapping via simulation: A process sector case study. International Journal of Production Economics, 107(1), 223-236.

2. Braglia, M., Carmignani, G., \& Zammori, F. (2006, September 15). A new value stream mapping approach for complex production systems. International Journal of Production Research, 44(18/19), 3929-3952.

3. Carnes, K., \& Hedin, S. (2005, Fall). Accounting for Lean Manufacturing: Another Missed Opportunity?. Management Accounting Quarterly, 7(1), 28-35.

4. Cunningham, J. E., Fiume, O. J. (2003). Real Numbers: Management Accounting in a Lean Organization. North Carolina: Managing Times Press.

5. DeLuzio, M. (2006, December). Accounting for Lean. Manufacturing Engineering, 137(6), 83-89.

6. Detty, R., \& Yingling, J. (2000, January 20). Quantifying benefits of conversion to lean manufacturing with discrete event simulation: a case study. International Journal of Production Research, 38(2), 429-445.

7. Drickhamer, D. (2004, December). Lean Accounting: Novel Number Crunching. Industry Week/IW, 253(12), 49-52.

8. $\quad$ Dwyer, J. (2005, May). Lean and the bean counters. Works Management, 58(5), 38-39.

9. El-Haik, B., \& Al-Aomar, R. (2006). Simulation-Based Lean Six-Sigma And Desighn For Six-Sigma. New Jersey: Wiley-Interscience. 
10. Grasso, L. (2005, Fall). Are ABC and RCA Accounting Systems Compatible with Lean Management?. Management Accounting Quarterly, 7(1), 12-27.

11. Harrell, C., \& Tumay K. (1995). Simulation Made Easy: A Manager's Guide. Geotgia: Industrial Engineering and Management Press.

12. Harrell, C., Ghosh, B. K., \& Bowden, R. O. (2004). Simulation Using Promodel. New York: McGraw-Hill.

13. Jusko, J. (2007, September). Accounting For Lean Tastes. Industry Week/IW, 256(9), 35-37.

14. Kennedy, F., \& Brewer, P. (2006, September). The lean enterprise and traditional accounting-Is the honeymoon over?. Journal of Corporate Accounting \& Finance (Wiley), 17(6), 63-74.

15. Laburu, C. Ochoa, Lasa, I. Serrano, \& Vola, R. de Castro (2008). An evaluation of the value stream mapping tool. Business Process Management Journal, 14(1), 39-52.

16. Lian, Y., \& Van Landeghem, H. (2007, July). Analysing the effects of Lean manufacturing using a value stream mapping-based simulation generator. International Journal of Production Research, 45(13), 3037 3058.

17. Maskell, B., \& Baggaley, B. (2004). Practical Lean Accounting: A proven System for Measuring and Managing the Lean Enterprise. New York: Productivity Press.

18. Maskell, B., \& Kennedy, F. (2007, March). Why do we need lean accounting and how does it work? Journal of Corporate Accounting \& Finance (Wiley), 18(3), 59-73.

19. McDonald, T., Van Aken, E., \& Rentes, A. (2002, July). Utilising Simulation to Enhance Value Stream Mapping: A Manufacturing Case Application. International Journal of Logistics: Research \& Applications, 5(2), 213-232.

20. MCS Media (2006). The Lean Pocket Guide XL: Tools for the Elimination of Waste. Michigan: Author.

21. Meade, D., Kumar, S., \& Houshyar, A. (2006, April). Financial Analysis of a Theoretical Lean Manufacturing Implementation Using Hybrid Simulation Modeling. Journal of Manufacturing Systems, 25(2), 137-152.

22. Narasimhan, J., Parthasarathy, L., \& Narayan, P. S. (2007). Increasing the effectiveness of value stream mapping using simulation tools in engine test operations. Proceedings of 18th IASTED International Conference '07: Modelling and Simulation. Montreal, Quebec: Canada.

23. Rother, M., \& Shook, J. (2003). Learning to See: Value Stream Mapping to Create Value and Eliminate Muda. Massachusetts: The Lean Enterprise Institute.

24. Scullin, M. Eileen (2007). Integrating Value Stream Mapping And Simulation (Master of Science thesis, Brigham Young University, 2005), Web Reference http://patriot.lib.byu.edu/ETD/image/etd898.pdf Retrieved November 2008

25. Van der Merwe, A., \& Thomson, J. (2007, February). The Lowdown on Lean Accounting. (cover story). Strategic Finance, 88(8), 26-33.

26. Womak, J. P., \& Jones, D. T. (2003). Lean Thinking: Banish Waste And Create Wealth In Your Corporation. New York: Free Press. 
NOTES 